\title{
Promoting Informed Choice: Evaluating A Decision-Making Tool for Family Planning Clients And Providers in Mexico
}

\section{By Young Mi Kim, \\ Adrienne Kols, \\ Antonieta Martin, \\ David Silva, \\ Ward Rinehart, \\ Sarah \\ Prammawat, \\ Sarah Johnson and Kathryn \\ Church}

Young Mi Kim is senior advisor for research and evaluation; Adrienne Kols is consultant; Ward Rinehart is editor, the

INFO Project; and Sarah Prammawat is consultant-all with the Johns Hopkins Bloomberg School of Public Health, Center

for Communication Programs, Baltimore, MD, USA. Antonieta

Martin is regional

communications

officer, Population Council/FRONTIERS,

Mexico City. David

Silva is physician, Instituto Mexicano del

Seguro Social, Mexico

City. Sarah Johnson and Kathryn Church are technical officers, Department of Reproductive Health and Research, World Health Organization, Geneva.

\begin{abstract}
CONTEXT: The World Health Organization (WHO) has developed a decision-making tool to be used by providers and clients during family planning visits to improve the quality of services. It is important to examine the tool's usability and its impact on counseling and decision-making processes during family planning consultations.
\end{abstract}

METHODS: Thirteen providers in Mexico City were videotaped with family planning clients three months before and one month after attending a training session on the WHO decision-making tool. The videotapes were coded for clientprovider communication and eye contact, and decision-making behaviors were rated. In-depth interviews and focus group discussions explored clients' and providers' opinions of the tool.

RESULTS: After providers began using the decision-making tool, they gave clients more information on family planning, tailored that information more closely to clients' situations and more often discussed HIV/AIDS prevention, dual protection and condom use. Client involvement in the decision-making process and client active communication increased, contributing to a shift from provider-dominated to shared decision making. Clients reported that the tool helped them understand the provider's explanations and made them feel more comfortable talking and asking questions during consultations. After one month of practice with the decision-making tool, most providers felt comfortable with it and found it useful; however, they recommended some changes to the tool to help engage clients in the decision-making process.

CONCLUSIONS: The decision-making tool was useful both as a job aid for providers and as a decision aid for clients. International Family Planning Perspectives, 2005, 31(4):162-171

One of the many challenges in realizing informed choice in family planning is that people often find it difficult to make a decision when presented with a variety of health care options. They may not understand the options, they may have trouble weighing the pros and cons, and they may not have clarified in their own minds which attributes of the various family planning methods are most important to them. ${ }^{1}$ In such cases, people may need support to negotiate the decision-making process.

Yet, this kind of support has been lacking in many family planning programs. Dissemination of information is one well-documented area of weakness: Often, providers do not tailor information to clients' individual situations, and the information they do give-especially about clients' chosen methods-may be inaccurate and incomplete. ${ }^{2}$ Another weakness is providers' and clients' lack of understanding of their roles in the decision-making process. In some cases, for example, providers may believe that they know what is best for clients and that they should make all the decisions; in other cases, they may accept that family planning is the client's choice, but incorrectly believe that that means they should relinquish all involvement in the decision-making process. $^{3}$

The challenge is to find a balance between the client's and the provider's input into decision making. ${ }^{4}$ The client is ultimately responsible for choosing which method (if any) to use, but the provider should inform and support the client's efforts to make a decision. ${ }^{5}$

\section{DEVELOPING A DECISION-MAKING TOOL}

To help improve the quality of family planning services, the Department of Reproductive Health and Research at the World Health Organization (WHO) is leading the development of four evidence-based guidelines and tools. ${ }^{6}$ One of these is the Decision-Making Tool for Family Planning Clients and Providers, ${ }^{7}$ a two-sided flipchart with one side designed to function as a decision aid for clients and the other side to act as a job aid for providers.

Decision aids guide patients through a series of steps, giving them personalized information and helping them clarify their values regarding benefits and risks, ultimately aiding their choice of health care options. ${ }^{8}$ The WHO flipchart uses clients' pages with simple language and illustrations to raise key issues in an orderly decision-making process; providers expand on these messages during consultations and tailor the information to the needs of the client.

Job aids improve worker performance and make performance more consistent, by reducing guesswork, minimizing reliance on memory and promoting compliance with standards. ${ }^{9}$ The WHO flipchart functions as a job aid by supplying providers with directions, technical information, sample questions and statements, and counseling tips. 
Unlike other family planning flipcharts, the WHO flipchart uses a decision-making algorithm to systematically guide clients and providers through the counseling process. ${ }^{10}$ First, it categorizes clients on the basis of the reason for their visit: for example, to adopt a method that he or she is already interested in, to seek help for a problem that he or she is experiencing with a method, or to get emergency contraception. At each subsequent decision point, the provider seeks input from the client regarding his or her needs and preferences. In this way, the client-rather than the provider-drives the flow of the counseling process.

The flipchart seeks to improve the quality of family planning counseling by helping providers apply best practices in client-provider interactions; by guiding providers to respond to the client's expressed wishes and preferences at each step in the counseling process; by encouraging providers to give accurate, relevant and up-to-date technical information at appropriate points; and by promoting participation and informed choice by clients.

\section{STUDY OBJECTIVES}

A series of field tests launched in 2002 examined the usefulness, acceptability and effectiveness of the flipchart. ${ }^{11}$ Feedback from each test has been used to maximize the tool's impact on counseling and enhance its usability. In addition, the field tests have provided insight on how to adapt the generic flipchart to different cultural and service delivery settings, which is important when implementing it in any local context.

In this article, we report on a field test in Mexico that assessed the tool's effectiveness in changing the counseling and decision-making process, and collected feedback from providers and clients. We investigated whether training on and use of the flipchart has an impact on information given by providers, on client participation and on the quality of decision making; how the flipchart helps or hinders family planning counseling; how comprehensible, usable and acceptable it is to providers and clients; and what changes could increase its acceptability and impact.

\section{METHODS}

\section{Sample}

The study was conducted in 2003-2004 at nine government health facilities in Mexico City, including five maternity hospitals, two general hospitals, one primary health care clinic and one clinic at a women's prison. We selected these facilities to represent different geographic divisions in Mexico City; there was nothing unusual about the study facilities, all of which were typical Mexican hospitals or clinics. The director of each facility chose one or two providers who regularly served family planning clients to participate. Of the 13 providers chosen, nine were doctors, two were nurses and two were social workers. Three of the doctors were men; all other providers were women. The providers ranged in age from 29 to 39, and had an average of four years' experience. The doctors were obstetriciangynecologists or general practitioners who saw family plan- ning clients in the maternity ward or as outpatients. The nurses and social workers typically saw family planning clients first-during intake, on the maternity ward or at group talks in the waiting area-and then referred them to a doctor. All providers offered a wide range of services in addition to family planning.

\section{Intervention}

All of the participating providers received a copy of the WHO flipchart and attended a two-and-a-half-day training session. In the workshop, providers were taught how to navigate through the 100-page flipchart by using the tabs to move to the sections relevant to the client's situation, thus keeping the counseling session tailored, efficient and effective. The workshop also included the conceptualization of decision making, as well as role-playing and feedback.

Although the investigators recognized that distinguishing between the impact of the flipchart and that of the training would be a problem, it is unrealistic to expect providers to use the decision-making tool without any training. To minimize this issue, the workshop focused largely on the flipchart, devoted little time to basic counseling skills and interpersonal communication, and restricted technical information to topics that were new to the providers (i.e., dual protection, HIV/AIDS and emergency contraception).

At the end of the training session, the providers were instructed to use the flipchart with all their family planning clients for the next month. One of the trainers made a single follow-up visit to each provider during the two weeks after the workshop to give providers an opportunity to raise problems and get help using the flipchart.

\section{Data Collection}

The study design called for each provider to be videotaped with four clients (two new and two continuing)* three months before attending the training workshop and again one month after; however, we were able to videotape only 38 clients at baseline and 45 at postintervention because too few clients came for family planning services at some facilities on the day of data collection. In both the baseline and postintervention rounds, all clients were women; more than 90\% had children, and more than half had at least some high school education (Table 1, page 164). The IUD was the most common method: Sixty-six percent of clients at baseline and $60 \%$ of clients at postintervention were already using the method or decided during their session to use the method. The only significant difference between clients in the two rounds was age, with clients in the second round being somewhat younger than those at baseline.

For each videotaped session, a camera was placed so that the faces of both the provider and the client could be seen, thus permitting observation of eye contact. Remote microphones were used to improve sound quality. For the client's privacy, the video technician left the room after turning the

*New clients were defined as people who wanted to select a new method that day and, therefore, included some returning clients who wanted to switch methods. 


\begin{tabular}{|c|c|c|}
\hline Characteristic & $\begin{array}{l}\text { Baseline } \\
(\mathrm{N}=38)\end{array}$ & $\begin{array}{l}\text { Postintervention } \\
(\mathrm{N}=45)\end{array}$ \\
\hline \multicolumn{3}{|l|}{ Age $^{*}$} \\
\hline $17-24$ & 44.7 & 64.4 \\
\hline $25-34$ & 47.4 & 20.0 \\
\hline $35-50$ & 7.9 & 15.6 \\
\hline \multicolumn{3}{|l|}{ No. of children } \\
\hline 0 & 2.6 & 8.9 \\
\hline 1 & 39.5 & 31.1 \\
\hline 2 & 31.6 & 42.2 \\
\hline$\geq 3$ & 26.3 & 17.8 \\
\hline \multicolumn{3}{|l|}{ Education } \\
\hline selementary & 18.4 & 42.2 \\
\hline Some high school & 52.6 & 33.3 \\
\hline$\geq$ high school & 29.0 & 24.4 \\
\hline \multicolumn{3}{|l|}{ Type of client } \\
\hline Newt & 52.6 & 55.6 \\
\hline Continuing & 47.4 & 44.4 \\
\hline \multicolumn{3}{|c|}{ Client's contraceptive method‡ } \\
\hline IUD & 65.8 & 60.0 \\
\hline Implant & 15.8 & 11.1 \\
\hline Injectable & 7.9 & 8.9 \\
\hline Pill & 7.9 & 4.4 \\
\hline Condom & 2.6 & 15.6 \\
\hline Total & 100.0 & 100.0 \\
\hline
\end{tabular}

${ }^{*} p<.05$. New clients were defined as people who wanted to select a new method on the day of their clinic visit and, therefore, included some returning clients who wanted to switch methods. FIncludes the methods chosen by new clients during consultation and the methods of continuing clients.

camera on. Immediately after each consultation, a fieldworker conducted a private 5-10-minute exit interview with the client to collect social and demographic data. During the postintervention round, the exit interview also explored the client's opinions of the decision-making tool. We obtained written consent from providers and clients prior to videotaping and exit interviews.

After the second round of videotaping, the providers attended a one-day meeting to give feedback on the usefulness and usability of the decision-making tool. Each provider completed a written assessment form and participated in one of two focus group discussions. The discussions covered the tool's format, the decision-making process, communication with clients, technical information, training and scaling up the intervention. Each group presented a summary of their discussion to the other, prompting still more discussion.

In addition, four providers and two clients from the postintervention round agreed to take part in in-depth interviews of 1-3 hours each. Interviewers posed questions about the acceptability and usability of the flipchart. Providers watched and discussed one of their own counseling sessions on videotape during their interview.

\section{Data Analysis}

- Client-provider interaction. We used an adaptation of the Roter Interaction Analysis System (RIAS) developed for a study in Indonesia ${ }^{12}$ to analyze provider-client communi- cation from the videotaped consultations. The system assigns, on the basis of content, one of several dozen mutually exclusive codes to each utterance by a client or provider. An utterance is a phrase or sentence expressing a complete thought. Examples of codes are "gives medical information," "asks open-ended family planning question" and "shows concern or worry."

We constructed the dependent variables for the analysis by combining codes of interest into two categories: active client communication and facilitative provider communication. Active client communication gauged client participation in consultations, and measured when clients asked questions, sought clarification, expressed concern, sought reassurance, stated an opinion, paraphrased what the provider said, requested services and described her situation or condition. Facilitative provider communication gauged the extent to which providers fostered dialogue and rapport with clients and encouraged their participation, and measured when providers asked lifestyle and psychosocial questions, gave information and counseling on lifestyle and psychosocial issues, built partnerships with clients (e.g., self-disclosure, checking for understanding, asking for an opinion and stating an opinion), expressed positive emotion (e.g., approval, empathy, concern and reassurance) and showed agreement or understanding.

The videotapes were coded by a Mexican physician with experience with RIAS. She used the OBSERVER software package, which enabled her to code a videotaped session while watching it on a computer. Because of limited availability of computer hardware and software, she was able to code only 33 of the 38 baseline videotapes and 28 of the 45 postintervention videotapes. Although she coded at least one new and one continuing client consultation per provider per round, longer sessions were systematically excluded to save time. As a result, uncoded consultations in the postintervention round were an average of two minutes longer than coded sessions and were more likely than coded sessions to involve new clients. This raises the possibility of bias; however, we found no differences between decision-making tool scores from consultations that were and were not coded with RIAS. This suggests that the length of the sessions was not associated with the quality of counseling and that the results of the videotaped sessions are not biased.

-Decision making. We used an adaptation of the OPTION assessment tool to evaluate the decision-making process during the videotaped consultations. OPTION was designed to analyze decision making in developed-country medical encounters; ${ }^{13}$ later, the tool was adapted to analyze client and provider behavior during family planning consultations in Indonesia. ${ }^{14}$

For this study, we revised the assessment tool used in Indonesia so that sessions with new and continuing clients could be analyzed together. The revised tool assessed client involvement and provider performance on 13 key decisionmaking behaviors. Each behavior was rated on a five-point scale ranging from one (nonexistent behavior) to five (excellent performance), with the midpoint defined as the min- 


\begin{tabular}{|c|c|c|}
\hline Utterance & $\begin{array}{l}\text { Baseline } \\
(\mathrm{N}=33)\end{array}$ & $\begin{array}{l}\text { Postintervention } \\
(\mathrm{N}=28)\end{array}$ \\
\hline All & 95.1 & $190.4^{* * *}$ \\
\hline Client & 35.4 & $59.4 * * *$ \\
\hline Active communication & 2.3 & $5.3^{* * *}$ \\
\hline Othert & 33.1 & $54.1^{* * *}$ \\
\hline Provider & 59.7 & $131.0 * * *$ \\
\hline $\begin{array}{l}\text { Gave biomedical and family } \\
\text { planning information }\end{array}$ & 13.6 & $46.7^{* * *}$ \\
\hline Facilitative communication & 10.3 & $21.1^{* * *}$ \\
\hline Orientation & 9.6 & $36.1^{* * *}$ \\
\hline $\begin{array}{l}\text { Asked biomedical and family } \\
\text { planning questions }\end{array}$ & 17.7 & 19.5 \\
\hline Other & 8.5 & 7.6 \\
\hline
\end{tabular}

**** $\mathrm{p}<.001$. †Other client communication includes giving simple answers/ information on biomedical and family planning topics; showing agreement with or understanding of what the provider said; short responses to provider's orientation or instructions; and personal remarks.

imum desired level of performance based on family planning program expectations in developing countries. Results for each item are reported as mean ratings and as the percentage of sessions that meet minimum standards (i.e., with ratings of three or more). Overall decision-making scores were calculated by adding a client's or provider's scores for all 13 items; the highest possible score was 65 .

One of the investigators, who had extensive experience using the decision-making assessment tool, decided who made the decision in each consultation. ${ }^{*}$ It was considered largely or solely the provider's decision when the provider decided what the client should do without consulting the client, overruled the client's expressed preference or gave advice that the client accepted without question. It was considered largely or solely the client's decision when the client expressed a clear preference that the provider fulfilled after discussing the client's motivations or other options. A decision was considered shared when it emerged from the verbal exchange between the provider and the client, with each contributing. The rater assessed 80 videotaped sessions, working from transcripts that had been translated into English; transcripts of an additional three sessions were lost.

-Information giving. To assess how much technical information providers gave clients, we combined RIAS codes for giving family planning, medical and other routine information in one summary measure. Also, we separately analyzed one item from the decision-making assessment tool that rated providers on tailoring information about the pros and cons of family planning methods to the client's needs and circumstances.

-Eye contact. We appraised eye contact in the 33 baseline sessions and 28 postintervention sessions coded for RIAS using the OBSERVER package. The same investigator who rated decision making coded what clients and providers were looking at during the videotaped sessions into five categories: the provider or client; the flipchart; other information, education and communication materials; papers or forms; and elsewhere.
-Usability and acceptability. To assess providers' and clients' reactions to the flipchart, we read and extracted key findings from clients' exit interview forms, providers' assessment forms, transcripts of in-depth interviews with clients and providers, and written summaries of the providers' focus group discussions.

The WHO flipchart may have a greater impact on some types of providers than on others. The sample of providers included in this study, however, was too small to allow us to draw definitive conclusions. Therefore, we looked for differences between doctors and other providers (i.e., nurses and social workers), but no differences were found on measures of client-provider interaction or decision making, either within each round of data collection or over time (data not shown). Hence, findings are presented for all providers, regardless of type.

\section{RESULTS}

\section{Client-Provider Interaction}

Compared with clients at baseline, postintervention clients spoke more and participated more actively in consultations with providers. The total amount of client communication increased from an average of 35 utterances per session at baseline to 59 per session during the postintervention round (Table 2). Active client communication increased from two to five utterances per session. The decision-making tool directly prompted some of this active communication: In the videotapes, clients sometimes asked for explanations of the illustrations or text in the flipchart. Brief acknowledgments of providers' explanations and instructions account for most of the remaining increase in client communication.

Similarly, providers spoke more in the consultations using the flipchart than at baseline, with total provider communication increasing from 60 to 131 utterances per session. Facilitative communication-when providers encouraged client participation-increased from 10 to 21 utterances per session. Orientation statements increased even more, from 10 to 36 utterances per session. This is because the orientation category contained a lot of content directly related to the flipchart, including statements directing the client's attention to it and explanations of issues raised by it, such as confidentiality, the decision-making process, the role of the client and the provider, and dual protection. There was no increase in asking questions or other types of provider communication.

Greater communication by clients and providers led to an increase in the average length of the counseling sessions, from six minutes at baseline to 10 minutes postintervention (not shown). The proportion of communication contributed by providers and clients remained about the same, with providers contributing $63 \%$ of conversation at baseline and 69\% after the intervention. In focus group discussions, providers said that the increased time signified an improvement in counseling, because it allowed for more

*In a previous study, when this investigator rated $10 \%$ of the transcripts a second time to assess the reliability of her coding in a past study, intracoder reliability was $90 \%$ (source: reference 15 ). 


\begin{tabular}{|c|c|c|c|c|c|}
\hline Client's behaviors & $\begin{array}{l}\text { Baseline } \\
(\mathrm{N}=35)\end{array}$ & $\begin{array}{l}\text { Postinter- } \\
\text { vention } \\
(\mathrm{N}=45)\end{array}$ & Provider's behaviors & $\begin{array}{l}\text { Baseline } \\
(\mathrm{N}=35)\end{array}$ & $\begin{array}{l}\text { Postinter- } \\
\text { vention } \\
(\mathrm{N}=45)\end{array}$ \\
\hline Gives reason for visit & 2.9 & $42.2^{* * *}$ & Asks reason for visit & 0.0 & $44.4^{* * *}$ \\
\hline Identifies problem requiring a decision & 0.0 & $48.9^{* *}$ & Identifies problem requiring a decision & 2.9 & $55.6^{* * *}$ \\
\hline $\begin{array}{l}\text { Acknowledges her right to choose the } \\
\text { method/action that best suits her }\end{array}$ & 0.0 & $40.0^{* * *}$ & $\begin{array}{l}\text { Explains that different family planning } \\
\text { methods suit different people and } \\
\text { that the client has the right to choose }\end{array}$ & 2.9 & $46.7^{* * *}$ \\
\hline $\begin{array}{l}\text { Acknowledges her responsibility to } \\
\text { participate }\end{array}$ & 0.0 & $33.3^{* * *}$ & Discusses client's responsibility to participate & 0.0 & $37.8^{* * *}$ \\
\hline Expresses her desire for a certain method & 0.0 & $64.4^{* * *}$ & $\begin{array}{l}\text { Asks if client has a method in mind } \\
\text { and, if so, which one }\end{array}$ & 0.0 & $73.3^{* * *}$ \\
\hline $\begin{array}{l}\text { Describes her personal needs and } \\
\text { priorities for using a method }\end{array}$ & 0.0 & $60.0^{* * *}$ & Probes client's needs and priorities & 0.0 & $68.9 * * *$ \\
\hline Asks for or about alternative methods & 2.9 & $44.4^{* * *}$ & Mentions $>1$ family planning method & 11.4 & $55.6^{* * *}$ \\
\hline $\begin{array}{l}\text { Says what she likes and dislikes about } \\
\text { different methods }\end{array}$ & 0.0 & $57.8^{* * *}$ & $\begin{array}{l}\text { Tailors information about method pros and } \\
\text { cons to client's needs }\end{array}$ & 2.9 & $75.6^{* * *}$ \\
\hline $\begin{array}{l}\text { Asks questions during the decision- } \\
\text { making process }\end{array}$ & 0.0 & $62.2^{* * *}$ & $\begin{array}{l}\text { Offers the client explicit opportunities to } \\
\text { ask questions }\end{array}$ & 2.9 & $60.0^{* * *}$ \\
\hline $\begin{array}{l}\text { Seeks clarification during the decision- } \\
\text { making process }\end{array}$ & 0.0 & $68.9^{* * *}$ & $\begin{array}{l}\text { Checks that the client has understood the } \\
\text { information }\end{array}$ & 0.0 & $75.6^{* * *}$ \\
\hline $\begin{array}{l}\text { Expresses comfort level with making } \\
\text { the decision and whether she wants } \\
\text { help from the provider or to consult } \\
\text { with a partner }\end{array}$ & 0.0 & $24.4^{* * *}$ & $\begin{array}{l}\text { Explores client's comfort level with making } \\
\text { the decision and whether she wants help } \\
\text { from provider or to consult with a partner }\end{array}$ & 0.0 & $33.3^{* * *}$ \\
\hline Plays an active role in decision making & 2.9 & $46.7^{* * *}$ & $\begin{array}{l}\text { Provides an opportunity for the client to } \\
\text { choose a method, and verifies choice }\end{array}$ & 0.0 & $48.9^{* * *}$ \\
\hline $\begin{array}{l}\text { Mentions possibility of switching/ } \\
\text { discontinuing method in the future }\end{array}$ & 0.0 & $35.6^{* * *}$ & $\begin{array}{l}\text { Discusses possibility of switching/ } \\
\text { discontinuing method in the future }\end{array}$ & 0.0 & $40.0^{* * *}$ \\
\hline
\end{tabular}

dialogue with clients and more opportunity to give clients information on the contraceptive method they chose or were already using. However, providers expressed concern about spending additional time with clients because of heavy patient loads.

\section{Decision Making}

Clients' overall decision-making score-the sum of all 13 items in the decision-making assessment tool-increased from an average of 19 at baseline to 32 in the postintervention round (not shown). For each item, there was a significant increase at postintervention in the proportion of sessions in which clients met at least the minimum level of desired behavior (Table 3). The greatest improvements were in seeking clarification (0\% vs. 69\%), expressing a desire for a certain contraceptive method ( $0 \%$ vs. 64\%), asking questions (0\% vs. 62\%) and describing personal needs and priorities for using a method (0\% vs. 60\%).

Providers' overall decision-making score increased from an average of 20 at baseline to 34 in the postintervention round (not shown). As with clients, there was a significant increase postintervention in the proportion of sessions in which providers met at least the minimum level of desired performance for each item in the decision-making assess- ment tool (Table 3). The greatest improvements in provider behavior were in checking that the client understood information (0\% vs. $76 \%$ ) and asking whether the client had a method in mind and validating her choice (0\% vs. 73\%). Every provider improved, although some made greater gains than others (not shown). Scores for individual providers increased from the baseline to the postintervention round by $25 \%$ to $86 \%$. The improvement occurred in sessions with both new and continuing clients.

From baseline to postintervention, there was a significant shift from provider-dominated to shared decision making (not shown). During the baseline round, providers were solely responsible for decisions (e.g., to adopt or switch methods) in $44 \%$ of sessions and largely responsible in the remaining $56 \%$. After the intervention, providers were largely responsible for the decision in only $19 \%$ of sessions and shared the decision with clients in $81 \%$ of sessions.

Clients' decisions, as reflected in the methods clients left their sessions with, showed some change from baseline to postintervention. A smaller proportion of clients at baseline than at postintervention decided to use condoms ( $3 \%$ vs. $16 \%$ ), whereas greater proportions chose the IUD (66\% vs. $60 \%$ ), the implant (16\% vs. $11 \%$ ) or the pill ( $8 \%$ vs. $4 \%$ ). The sample sizes for each method were too small to calcu- 
late significance individually; the overall change in the method mix, however, was not statistically significant.

\section{Information Giving}

In interaction analysis, providers gave clients significantly more information on family planning in the postintervention sessions-with the aid of the flipchart - than in the baseline sessions (47 vs. 14 utterances per session-Table 2). Although giving more information is not necessarily better, as it can overwhelm clients and distract from key points, ${ }^{15}$ providers in the focus group discussions said that before beginning to use the flipchart, they had given clients insufficient information to make an informed decision. This suggests that increased information giving may be an improvement in this setting. In addition, providers did a significantly better job during the postintervention round than during the baseline round of tailoring information about the pros and cons of methods to each client's needs and circumstances: At baseline, only 3\% of consultations met minimal standards for tailored information-giving, compared with $76 \%$ during the postintervention round (Table 3 ). This suggests that providers understood and successfully implemented the flipchart's goal of client-based counseling.

During the training workshop, providers disagreed about whether it was appropriate to discuss HIV prevention with family planning clients in Mexico, given the low levels of the disease in the client population. They decided that it was worth trying, and as a result of this consensus and of the prompts incorporated in the flipchart, discussion of HIV prevention, dual protection and condom use increased significantly from baseline to postintervention (not shown). During the baseline round, providers never mentioned HIV prevention or dual protection, and discussed condoms in only one session. In contrast, providers talked about these topics in $81 \%, 79 \%$, and $60 \%$ of postintervention sessions, respectively. And according to the videotapes, providers used the flipchart's tabbed sections on dual protection and condom use and also acted on its prompts to have clients consider HIV risks as part of the decision-making process.

\section{Eye Contact}

During the development of the flipchart, there was some concern that its two-sided design would create a barrier between providers and clients, breaking eye contact and undermining the interaction. However, providers reported in the group discussions that it was easy to look back and forth between the tool and the client. Also, the videotapes show that providers often looked at the client's side of the flipchart along with the client, which may be a more natural way to use the tool. And during in-depth interviews and group discussions, clients and providers mentioned that loss of eye contact did not necessarily diminish the quality of providers' attention to clients.

Quantitative measures of eye contact support these conclusions (Table 4). During the postintervention round, clients and providers looked at the flipchart for at least $170 \mathrm{sec}-$ onds (about one-third of the total time spent in consulta-

\begin{tabular}{|c|c|c|c|c|}
\hline \multirow[t]{2}{*}{ Eyes directed at } & \multicolumn{2}{|l|}{ Clients } & \multicolumn{2}{|l|}{ Providers } \\
\hline & $\begin{array}{l}\text { Baseline } \\
(\mathrm{N}=33)\end{array}$ & $\begin{array}{l}\text { Postinter- } \\
\text { vention } \\
(\mathrm{N}=28)\end{array}$ & $\begin{array}{l}\text { Baseline } \\
(\mathrm{N}=33)\end{array}$ & $\begin{array}{l}\text { Postinter- } \\
\text { vention } \\
(\mathrm{N}=28)\end{array}$ \\
\hline Provider/client & 153.0 & $293.9^{* * *}$ & 138.6 & $327.7^{* * * *}$ \\
\hline Flipchart & na & 186.9 & na & 170.0 \\
\hline Other client educational materials & 34.6 & $8.7^{*}$ & 29.2 & $6.9^{* *}$ \\
\hline Forms/papers & 44.5 & $15.0^{*}$ & 86.4 & $22.0^{* * *}$ \\
\hline Anywhere else & 33.0 & 45.9 & 20.1 & 23.4 \\
\hline Total & 265.1 & $550.4^{* * *}$ & 274.3 & $550.0^{* * *}$ \\
\hline
\end{tabular}

${ }^{*} \mathrm{p}<.05 .{ }^{* *} \mathrm{p}<.01 .{ }^{* * *} \mathrm{p}<.001$. Notes: na=not applicable. The flipchart was not used during the baseline round.

tion). However, about half of this added time was offset by reductions in time spent looking at other informational materials and at forms or papers. Longer sessions contributed to a significant increase in the absolute amount of time during which clients and providers looked at one another, which almost doubled for clients and more than doubled for providers. In contrast, the proportion of the consultation during which clients and providers looked at one another changed little, remaining at about 53-55\% for clients and rising from $50 \%$ to $60 \%$ for providers.

\section{Usability and Acceptability}

During the interviews and focus group discussions, clients and providers generally said that the format and content of the flipchart were appropriate and helpful. Clients reported that the flipchart made them feel more comfortable asking questions, less nervous about talking with the provider and more satisfied with the consultation. In addition, they said that the illustrations and text helped them understand the provider's explanations. Furthermore, clients were happy that the flipchart helped providers answer their questions.

Providers concluded that the flipchart was not as difficult or confusing to use as they had feared during the training session. After one month of practice with the tool, most providers felt comfortable with it and found it useful, both for themselves and for clients. A review of the videotapes by the investigators confirmed that most providers used the flipchart competently during the postintervention round.

Providers' success in using the flipchart indicates that two-and-a-half days of training were sufficient to teach them how to use it. However, providers recommended more training on counseling and communication skills, including more explicit instructions on how providers can help clients make decisions. Because preservice and continuing training in Mexico has operated on the assumption that service providers know what is best for clients, providers found the goal of engaging clients in the decision-making process especially challenging. To help meet that goal, they felt the tool should more clearly and explicitly communicate clients' responsibility for and role in decision making, the concept of decision making (by narrowing the number of options as opposed to considering each option individually) and how to weigh the pros and cons of different options. 
In addition, providers had many suggestions on how to adapt the flipchart to the Mexican setting. They recommended simplifying the wording and adding more illustrations on clients' pages to make the content easier for lesseducated women to understand; using local terms for contraceptive methods and procedures; adding more information on postpartum counseling, because family planning counseling in hospital maternity units is routine in Mexico City; and expanding the flipchart to cover client groups that are important locally, including adolescents with drug addictions, the mentally and physically disabled, sex workers and rape victims.

\section{DISCUSSION}

\section{Impact of the Decision-Making Tool}

This study examined the impact of the WHO flipchart in a real world scenario-as part of a package with limited but essential training. Some training is necessary to introduce the tool, partly because providers can find it difficult to navigate and partly because providers will continue to follow old counseling patterns in the absence of more explicit guidance. This has been seen in Indonesia, where providers were used to listing contraceptive options, asking the client which one she wanted and then describing that method. ${ }^{16}$ When given the flipchart to use, many providers skipped directly to the page showing all the method options, asked the client the usual question and then went straight to the section on that method, skipping the tool's carefully crafted algorithm and additional content.

Thus, it is difficult to distinguish between the impact of the flipchart and that of the associated training. To minimize this problem, we tried to restrict the content of the training session in Mexico to the flipchart itself and excluded such reinforcement mechanisms as supervision from the study, as the tool was designed to serve as a less expensive alternative to supervision in low-resource settings. Future studies could investigate different levels of training to shed further light on the relative contributions of the flipchart and the training to improve counseling and decision making.

What this study shows is that the flipchart, in combination with limited training in its use, improved the quality of family planning counseling and the decision-making process in three ways. First, use of the tool improved the amount of information offered to family planning clients. This is critical, because family planning counseling in Africa and Latin America have been shown to be deficient in this area. ${ }^{17}$ The flipchart may also improve the accuracy of information given, because it furnishes providers with technical information and answers to common questions; we did not examine accuracy in this study, however.

In addition, the flipchart prompted providers to tailor information to the client's situation, including his or her HIV risks. This client-centered approach to counseling enables providers and clients to quickly narrow down the choices. As a result, only the methods (or other courses of action) relevant to the client's needs and situation need be discussed at length. Eliminating provision of extraneous information is a positive step, because it focuses the consultation, reduces information overload for the client and expedites the decision-making process. ${ }^{18}$

Second, the WHO flipchart improved client involvement in the decision-making process. Family planning clients in many countries are passive: They say little, ask few questions and rarely assert their needs. ${ }^{19}$ The flipchart was designed to overcome many of the barriers that deter client communication and participation by redefining what behaviors are appropriate for family planning clients, by prompting clients to offer and ask for information, and by encouraging providers to give clients positive feedback when they speak out. Indeed, the flipchart makes the client's active involvement essential to the counseling process. Nearly every page calls for the provider to elicit the client's response to a key question or choice before the provider can know how to proceed. In response, clients in this study played a more active role in consultations that used the flipchart than in those that did not.

Third, the decision-making tool's support for the principle of informed choice led to a shift from providerdominated decision making to shared decision making. Use of the flipchart ensures that clients determine the course of the consultation, for example, by prompting providers to ask clients whether they want to learn about other methods or whether they need to consider dual protection. Also, the tool encourages providers to respect the client's right to choose a method or other course of action-as was evidenced by the rise in providers' scores on every item in the decision-making assessment tool.

Furthermore, the average length of sessions increased once providers began using the flipchart. Providers felt that the increased session length improved the quality of care. This interpretation is supported by a study of injectable counseling in Peru that found that the amount of useful information given to clients increased significantly as sessions grew in length from 2-8 minutes to 9-14 minutes; ${ }^{20}$ however, beyond 14 minutes, there were no further gains. This suggests that sessions that are too short may limit the provider's ability to convey essential information, but beyond a certain point, providers may not be able to use additional time effectively. In our study, the increase in session length from six minutes to 10 minutes suggests that the flipchart is prompting an appropriate increase in the length of the session to assure good quality counseling.

Providers in the study expressed concern about the feasibility of longer sessions. Although resources and client load vary widely among programs and among facilities, studies suggest that, in many settings, it is possible to make more time for counseling. Situation analyses in Sub-Saharan Africa found that client loads at most service delivery points were extremely low, which would leave time available for more thorough counseling. ${ }^{21}$ In addition, according to direct observations of providers in five countries in Africa and Latin America (including Mexico), providers typically spend half or less of their time with clients, and between one and three hours each day are either unoccupied or devoted to personal 
business. ${ }^{22}$ Furthermore, reorganizing the workload and client flow at a clinic can free more time for counseling. ${ }^{23}$

\section{Encouraging Providers to Use the Flipchart}

Job aids and decision aids can improve the performance of health care providers, but only if providers actually use them, which is often not the case. ${ }^{24}$ The WHO decision-making tool sidesteps one common problem: providers' reluctance to consult job aids in front of clients for fear that it puts their competence in question and undermines their credibility. ${ }^{25}$ Because the flipchart also functions as a decision aid for clients, its presence at the consultation is explained, which should make it more acceptable to providers. In addition, whether providers adopt or reject a tool depends on its ease of use, time requirements, relevance to the job at hand and consistency with providers' personal beliefs and professional practices, ${ }^{26}$ all these issues are relevant to the WHO flipchart, which looks complicated, lengthens consultation times and contradicts previous training and established practice in Mexico.

Field testing of the flipchart in Mexico, Indonesia and Nicaragua suggests several ways to overcome these problems and promote its use. The tool was designed in a generic format that most programs can use, but adapting it to local settings can make it more functional for providers and can generate interest and assure buy-in by policymakers and other stakeholders. Adaptation can consist of simple changes in terminology, method mix and referral procedures, or it can mean more complex changes in the structure of the tool, such as simplification for community-based workers or the addition of different client types. Adaptation need not be a costly or lengthy process, but local field testing may be necessary. WHO has developed an adaptation guide to help introduce the tool into reproductive health programs. Occasional updates will be necessary as new evidence changes current guidance on contraceptive use; however, the flipchart was designed to allow for insertion of new pages to avoid having to reproduce the entire tool.

Teaching providers the purpose of a new tool and how to use it is an essential part of introducing any job aid or decision aid. ${ }^{27}$ In this study, providers were able to master the flipchart with training and practice despite their initial worries about its size and apparent complexity. Also, the training workshop directly addressed the importance of client involvement in decision making and convinced providers of the value of the tool's approach to informed choice. WHO recommends a minimum of one day of training to introduce the tool and to instruct providers on how to use it. Programs can supplement this training with additional counseling skills and contraceptive technology as required. For some programs, however, even one day of training may be hard to implement. Thus, other strategies are being tested: For example, distance learning via training videos instructs midwives in Indonesia on the use of the flipchart.

Providers may need ongoing support and reinforcement if they are to continue using the flipchart after their initial enthusiasm wanes. ${ }^{28}$ According to a study in Guatemala, providers were far more likely to use a set of family planning job aids because they received a series of four followup visits by supervisors. ${ }^{29}$ Although the single site visit in our study helped providers transfer training on the flipchart to the work setting, there was no further follow-up. Yet, one year later, an informal survey of the 12 providers who could be located found that nine were continuing to use the flipchart, although only with certain types of clients. ${ }^{30}$ Only three had stopped using the tool, and they were equally likely to be doctors, nurses or social workers. Reinforcement strategies that might encourage providers to keep using the tool with clients include supervisory checklists that assess use of the flipchart and counseling skills, mentorship programs, peer support meetings and quality improvement programs that incorporate use of the tool.

\section{REFERENCES}

1. O'Connor AM, Légaré F and Stacey D, Risk communication in practice: the contribution of decision aids, BMJ, 2003, 327(7417): 736-740.

2. León FR et al., Length of counseling sessions and the amount of relevant information exchanged: a study in Peruvian clinics, International Family Planning Perspectives, 2001, 27(1):28-33 \& 46; Miller K, Jones $\mathrm{H}$ and Horn M, Indicators of readiness and quality: basic findings, in: Miller Ket al., eds., Clinic-Based Family Planning and Reproductive Health Services in Africa: Findings from Situation Analysis Studies, New York: Population Council, 1998, pp. 31-85; and Murphy E and Steele C, Client-provider interactions in family planning services: guidance from research and program experience, MAQ Papers, 2000, 1(2):1-12.

3. Kim YM, Kols A and Mucheke S, Informed choice and decisionmaking in family planning counseling in Kenya, International Family Planning Perspectives, 1998, 30(1):4-11 \& 42; and Rudy S et al., Improving client-provider interaction, Population Reports, 2003, Series Q, No. 1.

4. Rudy S et al., 2003, op. cit. (see reference 3).

5. EngenderHealth, Choices in Family Planning: Informed and Voluntary Decision Making, New York: EngenderHealth, 2003; O'Connor AM, Légaré F and Stacey D, 2003, op. cit. (see reference 1); and Upadhyay UD, Informed choice in family planning: helping people decide, Population Reports, 2001, Series J, No. 50.

6. Peterson HB et al., Norms and guidelines for use of methods of fertility regulation, in: World Health Organization (WHO), Annual Technical Report 2003, Geneva: WHO, 2004, pp. 71-76.

7. WHO and the INFO Project, Johns Hopkins Bloomberg School of Public Health Center for Communication Programs, Decisionmaking tool for family planning clients and providers, 2005, <http:// www.who.int/reproductivehealth/family_planning/tool.html>, accessed Dec. 13, 2005.

8. O'Connor AM, Llewellyn-Thomas HA and Flood AB, Modifying unwarranted variations in health care: shared decision making using patient decision aids, Health Affairs, Oct. 7, 2004, <http://content. healthaffairs.org/cgi/content/abstract/hlthaff.var.63vl>, accessed Dec. 3, 2004.

9. León FR et al., Enhancing quality for clients: the balanced counseling strategy, FRONTIERS Program Brief, Washington, DC: Population Council, 2003, No. 3; Moore T, State of the art in job aids: what they are and what is known, paper presented at the Job Aids Symposium, Washington, DC, May 2, 2001; Edward-Raj A and Phiri RK, Assessing the functionality of job aids in supporting the performance of IMCI providers in Zambia, <http://www.qaproject. org/pubs/PDFs/JobAidZambia.pdf>, accessed Oct. 11, 2005; Knebel $\mathrm{E}$, The use of manual job aids by health care providers: what do we know? <http://www.qaproject.org/pubs/PDFs/ISSUESJA.PDF>, accessed Oct. 11, 2005; and Mendez F et al., Screening family planning needs: an operations research project in Guatemala, <http:// 
www.biomedcentral.com/1472-698X/4/2>, accessed Oct. 11, 2005.

10. Rinehart W, Johnson S and Rudy S, A normative model of clientprovider communication for family planning decision-making, unpublished manuscript, Johns Hopkins Bloomberg School of Public Health, Center for Communication Programs, Baltimore, MD, USA, 2002.

11. Peterson HB et al., 2004, op. cit. (see reference 6)

12. Kim YM et al., Self-assessment and peer review: improving Indonesian service providers' communication with clients, International Family Planning Perspectives, 2000, 26(1):4-12; and Roter D, The Roter Interaction Analysis System (RIAS) Coding Manual, Baltimore, MD, USA: Johns Hopkins University School of Hygiene and Public Health, 1997.

13. Elwyn $G$ et al., Fleeting glimpses of shared decision making: developing the OPTION scale for measuring patient involvement, Quality \& Safety in Health Care, 2003, 12(2):93-99.

14. Kim YM et al., Participation by clients and nurse-midwives in family planning decision making in Indonesia, Patient Education and Counseling, 2003, 50(3):295-302.

15. Murphy E and Steele C, 2000, op. cit. (see reference 2).

16. Kim YM et al., unpublished data, Johns Hopkins Bloomberg School of Public Health, Baltimore, MD, USA, 2003.

17. León FR et al., 2001, op. cit. (see reference 2); and Miller K, Jones $\mathrm{H}$ and Horn M, 1998, op. cit. (see reference 2).

18. León FR et al., 2001, op. cit. (see reference 2); and Murphy E and Steele C, 2000, op. cit. (see reference 2).

19. Kim YM et al., 2003, op. cit. (see reference 14); Roter DL and Hall JA, Doctors Talking to Patients/Patients Talking to Doctors: Improving Communication in Medical Visits, Westport, CT, USA: Auburn House, 1992.

20. León FR et al., 2001, op. cit. (see reference 2).

21. Haberland N et al., Unrealized quality and missed opportunities in family planning services, in: Miller K et al., eds., Clinic-Based Family Planning and Reproductive Health Services in Africa: Findings from Situation Analysis Studies, New York: Population Council, 1998, pp. 127-139.

22. Hubacher D et al., Increasing efficiency to meet future demand: family planning services provided by the Mexican Ministry of Health, International Family Planning Perspectives, 1999, 25(3):119-124 \& 138; Janowitz B et al., How do providers spend their time: implications for the costs and quality of reproductive health services, paper presented at the annual meeting of the Population Association of America, Washington, DC, Mar. 29-31, 2001; and Janowitz B et al., Excess capacity and the cost of adding services at family planning clinics in Zimbabwe, International Family Planning Perspectives, 2002, 28(2):58-66

23. Setty V, Organizing work better, Population Reports, 2004, Series Q, No. 2.

24. Edward-Raj A and Phiri RK, 2002, op. cit. (see reference 9); and Léon FR et al., 2003, op. cit. (see reference 9).

25. Knebel E, 2000, op. cit. (see reference 9).

26. Edward-Raj A and Phiri RK, 2002, op. cit. (see reference 9); Knebel E, 2000, op. cit. (see reference 9); and O'Connor AM, Llewellyn-Thomas HA and Flood AB, 2004, op. cit. (see reference 8).

27. Knebel E, 2000, op. cit. (see reference 9); and O'Connor AM, Llewellyn-Thomas HA and Flood AB, 2004, op. cit. (see reference 8).

28. PRIME II and JHPIEGO, Transfer of Learning: A Guide for Strengthening the Performance of Health Care Workers, Chapel Hill, NC, USA: PRIME II and JHPIEGO, 2002; and RamaRao S and Mohanam R, The quality of family planning programs: concepts, measurement, interventions, and effects, Studies in Family Planning 2003, 34(4):227-248
29. León FR et al., 2003, op. cit. (see reference 9).

30. Martin A, unpublished data, Population Council/Frontiers, Mexico City, 2005.

\section{RESUMEN}

Contexto: La Organización Mundial de la Salud (OMS) ha desarrollado una herramienta de ayuda para la toma de decisiones con motivos de mejorar la calidad de los servicios de planificación familiar; se creó la herramienta para ser utilizada por los proveedores y clientes durante las visitas a los centros de planificación familiar. Es importante examinar la utilidad de esta herramienta y su impacto con respecto a los procesos de consejería y toma de decisiones durante las consultas de planificación familiar.

Métodos: Se filmaron las actividades de 13 proveedores de la Ciudad de México durante sus entrevistas con clientes de planificación familiar durante un período de tres meses previos y un mes después de su participación en sesiones de capacitación de la OMS sobre la herramienta. Se codificó la comunicación y la expresión de contacto ocular entre los clientes y los proveedores recogidas por los vídeos, y se les asignaron valores a las conductas observadas durante la toma de decisiones. Mediante entrevistas detalladas y deliberaciones de grupos focales se estudiaron las opiniones de los clientes y proveedores con respecto a esta herramienta para la toma de decisiones.

Resultados: Después que los proveedores comenzaron a usar la herramienta para la toma de decisiones, les suministraron a los clientes más información sobre planificación familiar, presentaron esta información en una forma más acorde a la situación de cada cliente, y se refirieron con mayor frecuencia a los temas de prevención de la infección del VIH/SIDA y a la protección dual y el uso del condón. Incrementaron la participación de los clientes en el proceso de toma de decisiones y la comunicación activa, lo cual contribuyó a un cambio del proceso que pasó de ser un asunto dominado por el proveedor a un ejercicio compartido por ambas partes. Los clientes indicaron que esta herramienta les ayudó a comprender las explicaciones de los proveedores y a sentirse más cómodos al hablar y formular preguntas durante sus consultas. Después de un mes de experiencia con esta herramienta, la mayoría de los proveedores se sintieron cómodos con este nuevo recurso y lo consideraron útil; sin embargo, recomendaron que se introdujeran ciertos cambios para facilitar la participación de los clientes en el proceso de la toma de decisiones. Conclusiones: La herramienta para la toma de decisiones fue útil tanto como un componente de ayuda para el trabajo de los proveedores como para la toma de decisiones de los clientes.

\section{RÉSUMÉ}

Contexte: L'Organisation mondiale de la santé (OMS) a mis au point un outil de décision à l'usage des prestataires et clientes du planning familial, dans le but d'améliorer la qualité des services. Il importe d'examiner l'impact de l'outil sur les processus de conseil et de décision durant les consultations de planning familial.

Méthodes: Treize prestataires de Mexico City (et leurs clientes) ont été filmés pendant les consultations de planning familial trois mois avant et un mois après leur participation à une formation sur l'outil de décision de l'OMS. Les bandes vidéo ont été codées en fonction de la communication et du contact visuel entre 
cliente et prestataire, avec évaluation des comportements décisionnels. Les opinions des clientes et des prestataires à l'égard de l'outil ont été explorées par le biais d'entretiens en profondeur et de discussions de groupe.

Résultats: Après ayant commencé à utiliser l'outil de décision, les prestataires offraient aux clientes une information plus complète sur le planning familial, adaptaient mieux cette information aux circonstances des clientes et abordaient plus souvent les questions de prévention du VIH/SIDA, de double protection et d'usage du préservatif. La participation des clientes au processus décisionnel et leur communication active ont du reste augmenté, contribuant à l'évolution d'une décision dominée par le prestataire vers une décision partagée. Les clientes ont indiqué que l'outil les aidait à comprendre les explications du prestataire et à s'exprimer et poser leurs questions plus aisément lors des consultations. Au bout d'un mois d'utilisation, la plupart des prestataires se sentaient à l'aise avec l'outil et le trouvaient utile, recommandant toutefois quelques modifications aptes à mieux engager les clientes dans le processus décisionnel.

Conclusions: L'outil de décision est utile tant au titre d'auxiliaire de travail pour les prestataires que d'aide à la décision pour les clientes.

\section{Acknowledgments}

This study was made possible by financial support from the U.S. Agency for International Development under cooperative agreement GPH-A-00-02-00003-00 with JHU/CCP/INFO. The authors thank Patricio Sanhueza and Anjarath Higuera for facilitating contacts with the providers; David Silva Bautista and Glenda Silva Bautista for data collection; Maribel Rodríguez for data analysis; Ricardo Vernon for office facilities and secretarial support; Debra Roter and Susan Larson for technical assistance in using RIAS; and Glyn Elwyn and Adrian Edwards for technical assistance in using OPTION.

Author contact:ykim@jhuccp.org 